\title{
NOTÍCIAS SOBRE O PATRIMÔNIO CULTURAL SUBAQUÁTICO INTERNACIONAL
}

No mês de setembro, por ocasião da Expo-98 - dedicada aos "Oceanos: Um Patrimônio para o Futuro"-, Lisboa também foi o centro das atenções e das discussões internacionais sobre o Patrimônio Cultural Subaquático e sobre a Arqueologia Subaquática. O Centro Nacional de Arqueologia Náutica e Subaquática (CNANS) de Portugal conseguiu reunir os maiores especialistas do mundo sobre tais temas, sediando a VII Reunião Anual do ICUCH - ICOMOS (International Committe on Underwater Cultural Heritage International Council on Monuments and Sites), e organizando o Simpósio Internacional "Arqueologia dos Navios Medievais e Modernos de Tradição Ibero-Atlântica". ${ }^{1}$

Embora os eventos tenham sido sucessos de contribuições preciosas à arqueologia naval e subaquática internacional, o destaque das discussões - e o escolhido por nós como tema desta nota, devido sua importância à nossa realidade - foi o Projeto de Convenção da UNESCO sobre a Proteção do Patrimônio Cultural Subaquático Internacional que integrará a "Convenção das Nações Unidas sobre o Direito do Mar" - DOALOS / ONU (Montego Bay, 1982).

A Convenção da UNESCO oficializa a importância do patrimônio cultural subaquático como parte integrante do patrimônio cultural da Humanidade, e, por temer o processo de destruição contínuo desse patrimônio - sobretudo através de ações criminosas de empresas de caça ao tesouro em países com problemas nas legislações -, passa a se ocupar das normas e dos procedimentos internacionais da ONU com o objetivo de garantir a proteção do patrimônio submerso, adotando, para tal, a Carta Internacional do ICOMOS para a Proteção e Gestão do Patrimônio Cultural Subaquático (Sofia, 1996) ${ }^{2}$

(1) Viagem patrocinada pela Fundação Municipal de Ensino Superior de Bragança Paulista (FESB) / SP.

(2) Carta publicada na Revista do Museu de Arqueologia e Etnologia, da Universidade de São Paulo, 7: 209-213, 1997; e na Revista de Arqueologia, da Sociedade de Arqueologia Brasileira, 9: 141-145, 1996. como dispositivo e princípio básicos de aplicação aos países membros.

\section{O Brasil no contexto internacional}

A situação brasileira atual está sendo compreendida internacionalmente como confusa e preocupante, pois, no dia 10 de dezembro de 1982 , o Brasil assinou com 118 países a "Convenção das Nações Unidas sobre o Direito do Mar". Esta Convenção - uma espécie de Constituição do Mar -, que, após várias ratificações de seu texto original, entrou em vigor internacional somente em 16 de novembro de 1994, traz em seu Texto Magno os Artigos 149, 303 e 33, voltados à proteção do patrimônio cultural subaquático. ${ }^{3}$

Vale destacar que "o decreto brasileiro $\mathrm{n}^{\circ}$ 1330 de 22 de junho de 1995 declarou a entrada em em vigor da Convenção internamente. (...) Esta Convenção tem o mesmo valor de uma constituição no plano interno. Ela tem uma hierarquia normativa em relação aos demais tratados internacionais e também uma predominância normativa em relação a atos internos dos Estados, sendo impossível elaborarmos normas sobre o mar sem levarmos em conta o contexto da Convenção". ${ }^{4}$

(3) Artigo 149: "Todos os objetos de caráter arqueológico e histórico achados na Área serão conservados ou deles se disporá em benefício da humanidade em geral, tendo particularmente em conta os direitos preferenciais do Estado ou país de origem, do Estado de origem cultural ou do Estado de origem histórica e arqueológica.

Artigo 303: "Os Estados têm obrigação de proteger os objetos de caráter arqueológico ou histórico descobertos no mar e devem cooperar para esse fim. A fim de controlar o tráfico de tais objetos, o Estado costeiro pode presumir, ao aplicar o Artigo 33, que a sua remoção dos fundos marinhos, na área referida neste artigo, sem a sua autorização constitui uma infração, cometida no seu território ou no seu mar territorial, das leis e regulamentos mencionados no referido artigo" (A Convenção da Nações Unidas sobre o Direito do Mar).

(4) O Brasil e a Convenção das Nações Unidas sobre o Direito do Mar. Anais do Seminário, ACIMA e PROCAM/ USP, 1996: 9. 
Neste sentido, como justificamos - enquanto Estado membro da ONU e da UNESCO - os projetos elaborados por deputados brasileiros ${ }^{5} \mathrm{e}$ apresentados recentemente no Congresso Nacional, para a modificação da lei $\mathrm{n}^{\circ} 7.542$ de 1986 (que enfatiza como pertencentes à União todos os bens de valor artístico, interesse histórico e arqueológico encontrados submersos), e principalmente do artigo 20 (responsável pela proibição da comercialização dos bens arqueológicos provenientes de sítios submersos)?

Recebido para publicação em 04 de janeiro de 1999.
(5) O "projeto original do ex-deputado Fábio Feldmann (PSDB-SP), atual Secretário do Meio Ambiente de São Paulo, permitia o livre ingresso de estrangeiros no país e o fim do domínio exclusivo da União sobre os bens culturais, artísticos e arqueológicos submarinos. Já o substitutivo do deputado Angelo Queiroz (PCdoB-DF), que está para ser votado na CCJ a partir de 15 de fevereiro (98), exige a associação de empresas estrangeiras e nacionais através de joint-ventures, assegurando o controle nacional do setor, $\mathrm{e}$ limita a $50 \%$ o repasse de bens de valor histórico, em dinheiro ou objetos, como pagamento aos exploradores." $(O$ Globo, 25/01/98).
Uma coisa é certa e merece nossa atenção, existe um desentendimento jurídico interno nacional, que carece de uma solução rápida, pois estamos indo na "contramão" do que vem sendo proposto internacionalmente para a proteção do nosso patrimônio cultural subaquático. Vale a reflexão!

Gilson Rambelli*
(*) Museu de Arqueologia e Etnologia da Universidade de São Paulo. Pós-graduação, Doutorado. Representante do ICOMOS/Brasil no ICUCH - ICOMOS ((International Committe on Underwater Cultural Heritage / Comitê Internacional do Patrimônio Cultural Subaquático). Departamento de História da Fundação Municipal de Ensino Superior de Bragança Paulista (FESB) / SP. 